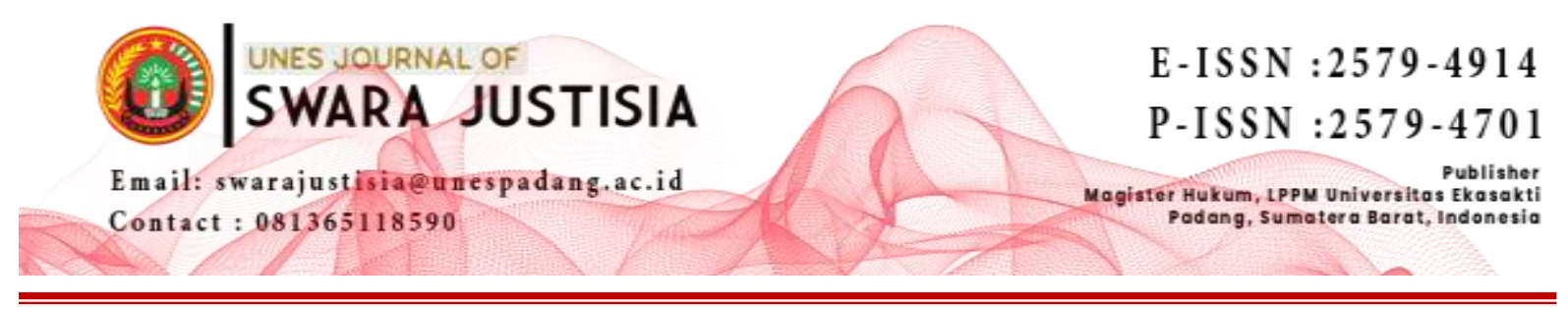

\title{
KEKUATAN PEMBUKTIAN SAKSI MAHKOTA PADA PERKARA PEMUFAKATAN JAHAT DALAM TINDAK PIDANA NARKOTIKA
}

\author{
Imra Leriwahyuli \\ Program Magister Ilmu Hukum,Universitas Ekasakti, Padang \\ Email: imrawahyuli@gmail.com
}

\begin{abstract}
The Evidence Power of Crown Witnesses in Decision Number 400/Pid Sus/2019/PN.Pdg With 401/Pid Sus/2019/PN.Pdg And Decision Number 09/Pid Sus/2019/Pn.Pdg With 10/Pid Sus/2019/PN .Pdg is the same as other witnesses if they have met the requirements as witnesses. The crown witness in the narcotics crime case is the main witness to reveal the crime. The use of crown witnesses is very important because in this criminal act it is very difficult to find witnesses who can explain the chronology of a case because there are no victims and more than one perpetrator. The application of the Penalty in the Decision is a violation of Article 114 of the Narcotics Law. both defendants were guilty of violating Article 114 paragraph (1) of Law Jo, Article 132 paragraph (1) of Law no. 35 of 2009 concerning Narcotics. The judge handed down the same sentence.
\end{abstract}

Keywords: Crown Witness, Narcotics, Criminal

\begin{abstract}
ABSTRAK
Surat Kuasa Saksi Mahkota dalam Putusan Nomor 400/Pid Sus/2019/PN.Pdg Dengan 401/Pid Sus/2019/PN.Pdg Dan Putusan Nomor 09/Pid Sus/2019/Pn.Pdg Dengan 10/Pid Sus/2019 /PN .Pdg sama dengan saksi lainnya apabila telah memenuhi syarat sebagai saksi. Saksi mahkota dalam perkara tindak pidana narkotika merupakan saksi utama untuk mengungkap tindak pidana tersebut. Penggunaan saksi mahkota sangat penting karena dalam tindak pidana ini sangat sulit mencari saksi yang dapat menjelaskan kronologis suatu perkara karena tidak ada korban dan pelaku lebih dari satu. Penerapan Pidana dalam Putusan tersebut merupakan pelanggaran terhadap Pasal 114 UU Narkotika. kedua terdakwa terbukti melanggar Pasal 114 ayat (1) UU Jo Pasal 132 ayat (1) UU No. 35 Tahun 2009 tentang Narkotika. Hakim menjatuhkan hukuman yang sama.
\end{abstract}

Kata Kunci: Saksi Mahkota, Narkotika, Kriminal

\section{PENDAHULUAN}

Pasal 1 ayat (3) Undang-undang Dasar Negara Republik Indonesia Tahun 1945 menyebutkan, bahwa Indonesia adalah negara berdasarkan atas hukum (rechtsstaat) tidak berdasarkan atas kekuasaan belaka (machstssat). Hal ini berarti bahwa Negara Republik Indonesia adalah Negara hukum yang demokratis berdasarkan Pancasila dan UUD 1945 menjunjung tinggi hak asasi manusia dan menjamin segala warga Negara berkesamaan 
kedudukannya dihadapan hukum dan pemerintahan,serta wajib menjunjung tinggi hukum dan pemerintahan itu tanpa ada pengecualiannya.

Keterangan saksi merupakan salah satu alat bukti yang diatur dalam Pasal 184 Undang Undang Nomor 8 Tahun 1981 tentang Kitab Undang undang Hukum Acara Pidana. Saksi adalah seseorang yang dapat memberikan keterangan untuk kepentingan penyidikan, penuntutan dan peradilan tentang suatu perkara pidana yang ia dengar sendiri, ia lihat sendiri dan ia alami sendiri. Berpedoman kepada uraian tersebut di atas, keberadaan seorang saksi akan menjadi "kata kunci" dalam pengungkapan sebuah perkara pidana. Oleh karena, jika tidak ada orang yang melihat, tidak ada orang yang mendengar dan tidak ada orang yang mengalami sendiri tentang terjadinya tindak pidana, maka aparat hukum akan kesulitan menangkap pelakunya. Kesulitan yang sama juga akan dialami oleh aparat hukum, apabila ada seseorang yang dapat diperankan sebagai saksi, sementara mereka tidak memberikan kesaksiannya. Terhadap kemungkinan yang terakhir ini, kelihatannya bukan sesuatu yang mustahil untuk terjadi, dimana oleh karena pertimbangan tertentu, seseorang enggan menjadi saksi.

Peranan saksi dalam setiap persidangan perkara pidana sangat penting karena kerap keterangan saksi dapat mempengaruhi dan menentukan kecendrungan putusan hakim.Seorang saksi dianggap memiliki kemampuan yang dapat menentukan kemana arah putusan hakim.Hal ini memberikan efek kepada setiap keterangan saksi selalu mendapat perhatian yang sangat besar baik oleh pelaku hukum yang terlibat didalam persidangan maupun oleh masyarakat pemerhati hukum. Oleh karena itu, maka seorang saksi sering mendapat berbagai ancaman baik secara mental maupun fisik, karena tersangkut berbagai pihak dalam kasus kasus yang diperiksa.

Pada Putusan Mahkamah Agung Nomor 2437K /Pid.Sus/2011 yang menyebutkan bahwa walaupun tidak memberikan suatu definisi otentik dalam KUHAP mengenai saksi mahkota (Kroongetuide), namun berdasarkan presfektif empirik maka saksi mahkota di definisikan sebagai saksi yang berasal atau di ambil dari salah seorang tersangka atau terdakwa lainnya yang bersama-sama melakukan tindak pidana. Kepada saksi tersebut diberikan mahkota, adapun mahkota yang diberikan kepada saksi yang berstatus terdakwa tersebut adalah dalam tindakan penuntutan terhadap perkaranya atau diberikan tuntutan yang sangat ringan apabila perkara dilimpahkan ke pengadilan atau dimaafkan atas kesalahan yang pernah dilakukan.

Dasar hukum lainnya tentang saksi mahkota dapat ditemukan pada Surat Edaran Kejaksaan Agung Nomor B 69/E/02/1997 tahun 1997 tentang hukum pembuktian dalam perkara pidana. Pada surat Edaran Kejaksaan Agung tersebut juga menjelaskan mengenai saksi mahkota adalah sebagai berikut dalam KUHAP tidak terdapat istilah saksi mahkota, namun sejak sebelum berlakunya KUHAP, istilah saksi mahkota sudah di kenal lazim di ajukan sebagai alat bukti namun berita acara pemeriksaan istilah tersebut tidak pernah dicantumkan. Praktek saksi mahkota digunakan dalam hal terjadinya penyertaan (deelneming) dimana terdakwa yang satu dijadikan saksi terhadap terdakwa lainnya oleh karena alat bukti yang lain tidak ada atau sangat minim.

Atas dasar hukum tersebut diatas kemudian memperhatikan tindak pidana peredaran gelap Narkotika yang banyak melibatkan pelaku-pelaku yang memiliki peran berbeda-beda yang tidak terlepas dari suatu perbuatan pemufakatan jahat maka penulis ingin meneliti 
mengenai kekuatan pembuktian saksi mahkota pada tindak pidana narkotika dalam hal pemufakatan jahat, pada Putusan PN.Padang Nomor 401/Pid Sus/2019/PN.Pdg dan Putusan PN Padang Nomor 9 /Pid Sus /2019/Pn.Padang.

Adapun gambaran umum dari perkara nomor 401/Pid Sus/2019/PN.Pdg dan Putusan PN Padang Nomor 9 /Pid Sus /2019/Pn.Padang yaitu yang mana pada perkara dengan nomor 401/Pid Sus/2019/PN.Pdg terdakwanya yaitu saudara Albert Yakub Bin Marzuki Yakub Pgl Albert, perkara ini yaitu hasil pengembangan atas penangkapan dari terdakwa lainnya yang bernama Jefri Marison Bin Musbar Pgl Jejeng, sedangkan saksi Jefri Marison Bin Musbar Pgl Jejeng adalah merupakan terdakwa dalam berkas perkara terpisah yaitu perkara dengan nomor 400/Pid Sus/2019/PN.Pdg dan terdakwa Albert Yakub Bin Marzuki yakub pgl Albert Juga sebagai saksi dalam perkara dengan nomor 400/Pid Sus/2019/PN.Pdg tersebut, dalam perkara ini terjadinya percakapan melalui Hand Pone antara saudara Albert Yakub Bin Marzuki yakub pgl Albert dengan saudara Jefri Marison Bin Musbar Pgl Jejeng sehingga terjadi suatu pemufakatan jahat dalam hal melakukan tindak pidana Narkotika, Sedangkan mengenai perkara dengan nomor 9 /Pid Sus/2019/PN.Padang yaitu dengan terdakwa hendri ramadani Pgl Rama, yang mana terdakwa adalah merupakan saksi dalam perkara terpisah yaitu perkara dengan nomor 10/Pid Sus/2019/PN. Padang dengan terdakwanya yaitu saudara Roby bayu saputra, dan begitu pula Terdakwa Hendri Ramadani Pgl Rama juga menjadi saksi pada perkara dengan nomor 10/Pid Sus/2019/PN. Padang tersebut, pada perkara ini diantara mereka yang sama-sama menjadi terdakwa pada perkara terpisah dan juga sama-sama sebagai saksi, yang mana hubungan antara keduanya yaitu telah melakukan pemufakatan jahat dalam mengedarkan narkotika yaitu saudara Robi Bayu saputra menyuruh terdakwa Hendri Ramadhani Pgl Rama untuk mengantarkan narkotika jenis shabu kepada pihak pembeli narkotika dan kemudian dalam pengantaran tersebut saudara Hendri Ramadhani Pgl Rama tertangkap oleh pihak kepolisian.

Berdasarkan latar belakang pemikiran di atas, maka permasalahan adalahBagaimana kekuatan pembuktian saksi mahkota dan penerapan pidananya dalam Putusan Nomor 400/Pid Sus/2019/PN.Pdg dengan 401/Pid Sus/2019/PN.Pdg dan Putusan Nomor 09 /Pid Sus/2019/Pn.Pdg dengan 10/Pid Sus/2019/PN.Pdg

\section{METODE PENELITIAN}

Spesifikasi penelitian adalah deskriptif analitis, dengan metode pendekatan yuridis normative. Jenis data yang digunakan adalah data sekunder. Data sekunder diperoleh dari studi dokumen dan studi kepustakaan. Data yang diperoleh kemudian dianalisa secara kualitatif.

\section{PEMBAHASAN}

A. Kekuatan Pembuktian Saksi Mahkota Dalam Putusan Nomor 400/Pid Sus/2019/PN.Pdg Dengan 401/Pid Sus/2019/PN.Pdg Dan Putusan Nomor 09/Pid Sus/2019/Pn.Pdg Dengan 10/Pid Sus/2019/PN.Pdg

Pembuktian dalam perkara pidana ini diperlukan peraturan perundang undangan yang dijadikan pedoman untuk menerapkan ketentuan hukum acara pidana secara jujur dan tepat. Terkait tentang hukum acara pidana, yang menjadi rujukan utama para 
penegak hukum di Indonesia yaitu Undang-undang Nomor 8 Tahun 1981 tentang Kitab Undang-Undang Hukum Acara Pidana.

Proses pembuktian dalam tindak pidana narkotika yang mengandung unsur permufakatan jahat memang bukanlah suatu hal yang mudah, karena seperti yang diketahui perkara tindak pidana narkotika merupakan suatu perkara yang sangat kompleks apalagi yang mengandung permufakatan jahat. Sehingga dalam proses pembuktiannya kadangkala terhambat oleh kurang alat bukti, khususnya alat bukti saksi. Sebenarnya dengan dipenuhinya minimum dua alat bukti saja Hakim sudah dapat menilai suatu perkara pembunuhan telah terjadi dengan keyakinan yang didapat dari kedua alat bukti yang sah. Hal ini juga telah memenuhi pembuktian alat bukti minimum dalam KUHAP, namun dalam proses pembuktiannya terkadang Jaksa Penuntut Umum menghadirkan saksi mahkota seperti pada perkara tindak pidana narkotika pada Putusan Nomor 400/Pid Sus/2019/PN.Pdg Dengan 401/Pid Sus/2019/PN.Pdg Dan Putusan Nomor 09 /Pid Sus/2019/Pn.Pdg Dengan 10/Pid Sus/2019/PN.Pdg.

Pada perbuatan tindak pidana narkotika dengan permufakatan jahat atau biasa disebut dengan terdakwa yang bersama-sama melakukan tindak pidana kemudian dijadikan saksi dalam perkara yang telah di pisah (splitsing).Disinilah perdebatan penggunaan saksi mahkota dianggap melanggar hak-hak terdakwa yang diatur dalam KUHAP dikarenakan terdakwa tidak dibebani beban pembuktian, namun hal itu dikesampingkan dengan menjadikan terdakwa menjadi saksi hal ini sering disebut dalam istilah sebagai saksi mahkota.

Alat bukti keterangan saksi dalam hukum acara pidana merupakan hal yang sangat penting dan diutamakan dalam membuktikan kesalahan terdakwa, maka disini hakim harus cermat dan teliti dalam menilai alat bukti keterangan saksi ini, karena dengan alat bukti keterangan saksi ini akan lebih mengungkap peristiwanya, sebab saksi adalah mereka yang mendengar, melihat dan mengalami sendiri suatu peristiwa pidana. Tidak selamanya keterangan saksi dapat sah menjadi alat bukti yang mempunyai kekuatan pembuktian dalam pemeriksaan di persidangan.

Terkait dengan pengunaan saksi mahkota dalam perkara tindak pidana narkotika dengan permufakatan jahat dalam putusan Nomor 400/Pid Sus/2019/PN.Pdg Dengan 401/Pid Sus/2019/PN.Pdg Dan Putusan Nomor 09 /Pid Sus/2019/Pn.Pdg Dengan 10/Pid Sus/2019/PN.Pdgkedudukan, kekuatan pembuktiannya sama dengan saksi-saksi yang lain apabila telah memenuhi persyaratan persyaratan yang telah disebutkan diatas. Kekuatan pembuktian saksi mahkota dalam persidangan suatu tindak pidana sama dengan saksi-saksi yang lainnya, ketika keterangan saksi telah memiliki legalitas formal sebagai saksi. Pada perkara yang diteliti menjadi alat bukti yang utama karena merupakan saksi yang mengalami langsung tindak pidana tersebut dan kurangnya saksi yang dapat memberikan keterangan pada perkara ini.

Dalam tindak Narkotika penggunaan saksi mahkota sangat penting dikarenakan dalam tindak pidana ini sangatlah sulit untuk mendapatkan saksi yang dapat menjelaskan kronologis dari suatu perkara karena tidak ada korban dan pelaku lebih dari satu orang. Pelaku pada tindak pidana narkotika dengan permufakatan jahat masing masing dituntut secara dipisah dan tentunya dapat menjadi saksi untuk menjelaskan kronologis perkara 
dan saksi mahkota disini dipilih dihadirkan untuk menjelaskan kronologis perkara karena dialah yang melihat, mendengar dan mengalami sendiri pada saat kejadian perkara.

Dalam kasus tindak pidana narkotika pada Putusan Nomor 400/Pid Sus/2019/PN.Pdg Dengan 401/Pid Sus/2019/PN.Pdg Dengan 401/Pid Sus/2019/PN.Pdg kesaksian yang diberikan oleh masing masing terdakwa secara silang. Pada Putusan Nomor 400/Pid Sus/2019/PN.Pdg dengan terdakwa Jefri Marison yang menjadi saksi mahkota dalam perkara ini adalah Albert Yacub yang juga disidangkan secara terpisah pada putusan nomor 401/Pid Sus/2019/PN.Pdg dengan telah memenuhi unsur-unsur pasal yang didakwakan yaitu Pasal 114 ayat (2) UU No. 35 tahun 2009 tentang Narkotika. Dimana Albert dalam kesaksiannya menyatakan telah mengambil 7 paket Shabu pada beberapa tempat sebagaimana yang diperintahkan oleh terdakwa.

Tindak pidana disini dilakukan terdakwa dan saksi mahkota secara bersama sama dengan cara albert meletakan barang berupa shabu pada suatu tempat tertentu yang disepakati. Kemudian setelah mengetahuinya terdakwa langsung pergi ke lokasi sendirian dan mengambil barang tersebut.Hal ini telah dilakukan beberapa kali. Paket tersebut atas suruhan saksi ALBERT terdakwa letakkan yang pertama sebanyak 2 (Dua) paket narkotika jenis shabu di tiang merk Colombia yang berada di jalan Nipah Kota Padang, yang kedua sebanyak 2 (Dua) paket dan 1 (Satu) paket narkotikan jenis shabu terdakwa letakkan ditanggul gang depan toko Kristin Hakim yang berada di Jalan Nipah dalam Kota Padang, yang ketiga 3 (Tiga) narkotika jenis shabu terdakwa letakkan di gang dekat karaoke Charly yang berada di jalan gang Berok I Kota Padang, yang keempat terdakwa letakkan di gang dekat masjid Nipah sebanyak 2 (Dua) paket narkotika jenis shabu. Bahwa sisa dari paket sedang diduga narkotika jenis shabu yang terdakwa terima yaitu 1 (Satu) paket sedang terdakwa masukkan ke dalam kotak rokok sampurna mild kemudian tersangka letakkan di dekat plang cafe Lekers yang berada di Jalan Cokroaminoto dan 1 (Satu) paket sedang tersangka masukan ke dalam kotak rokok sampurna mild kemudian tersangka letakkan di samping tempat pijat KAKIKU yang berada di jalan Nipah Kota Padang. Sehingga dari 10 (Sepuluh) paket yang diambil oleh terdakwa terdapat sisa sebanyak 7 (tujuh) paket sedang yang masih disimpan oleh terdakwa yang akan segera diantarkan oleh terdakwa jika ada instruksi dari saksi Albert.

Pada Putusan Nomor 9/Pid Sus /2019/Pn.Padang dengan Putusan Nomor 10/Pid Sus/2019/PN.Pdg dimana terdakwa pada Putusan Nomor 9/Pid Sus /2019/Pn.Padang dan terdakwa pada Putusan Nomor 10/Pid Sus /2019/Pn.Padang masing masing menjadi saksi mahkota pada perkara keduanya. Karena saksi Roby Saputra (terdakwa pada Putusan Nomor 10/Pid Sus /2019/Pn.Padang) dan Saksi Hendri Ramdani (terdakwa pada Putusan Nomor 9/Pid Sus /2019/Pn.Padang) telah melakukan permufakatan jahat dengan cara bersama sama melakukan tindak pidana narkotika yang memenuhi unsur unsur pada Pasal 114 ayat (1) UU No. 35 Tahun 2009 Jo pasal 132 ayat (1) UU No. 35 Tahun 2009 tentang Narkotika.

Pada perkara ini Bahwa ia terdakwa HENDRI RAMADANI PGL. RAMA bersama-sama dengan ROBY BAYU SAPUTRA Als.TOBING (dalam perkara terpisah). Roby Bayu Saputra Als. Tobing melakukan transaksi jual beli shabu dengan Hendri Ramadani. Terdakwa telah melakukan Percobaan dan Permufakatan jahat untuk melakukan tindak pidana,tanpa hak atau melawan hukum menawarkan untuk dijual, 
menjual, membeli, menerima, menjadi perantara dalam jual beli, menukar, atau menyerahkan narkotika golongan I jenis shabu (Metamfetamina) seberat 0,09 (nol koma nol sembilan) gram tanpa izin dari pihak yang berwenang. Perbuatan terdakwa sebagaimana diatur dan diancam pidana dalam Pasal 114 ayat (1) UU No. 35 Tahun 2009 Jo pasal 132 ayat (1) UU No. 35 Tahun 2009 tentang Narkotika.

Keterangan Albert dan jefri sebagai saksi mahkota memenuhi syarat sebagai alat bukti yaitu sebagai saksi dalam Putusan Nomor 400/Pid Sus/2019/PN.Pdg Dengan 401/Pid Sus/2019/PN.Pdg Dengan 401/Pid Sus/2019/PN.Pdg yang memenuhi syarat sebagaimana tertuang dalam pasal 1 angka 27 yaitu dimana Albert menyatakan keterangan sesuai dengan apa yang ia lihat, ia dengar dan dialami sendiri dalam perkara yang terdakwanya adalah Jefri. Keterangan Albert yang menyatakan bahwa benar adanya perbuatan tindak pidana narkotika yang dilakukan Jefri dan dirinya. Menunjukan bahwa Albert walaupun ia memberikan keterangan sesuai yang dialami dan dilihatnya dengan menerangkan terjadinya tindak pidana narkotika. Keterangan Albert dalam berperan sebagai saksi mahkota memenuhi syarat sebagai alat bukti saksi sesuai dengan pasal 160 ayat 3 KUHAP. Albert walaupun merupakan terdakwa dari perkara lain yang dipisah. Albert sebagai saksi mahkota memberikan perannya dalam memberikan keterangan.

Albert memberikan keterangan di sidang pengadilan terkait peristiwa tindak pidana untuk memberikan keterangan yang bersifat kebenaran materiil. Maka keterangan Albert dan jefri dapat dikatakan sebagai alat bukti karena sudah memenuhi unsur dalam pasal 1 angka 27 sebagai alat bukti saksi dan mempunyai nilai pembuktian karena telah diucapkan sumpah sebelum memberikan keterangan sesuai pasal 160 ayat (3) KUHAP dan keterangan diucapkan dimuka persidangan sesuai pasal 185 ayat (1) KUHAP. Keterangan saksi mahkota saja tidak cukup, supaya dapat dianggap cukup membuktikan kesalahan seorang terdakwa harus dipenuhi paling sedikit atau sekurang-kurangnya dengan dua alat bukti. Kalau begitu keterangan seorang saksi saja baru bernilai sebagai satu alat bukti yang harus ditambah dan dicukupi dengan alat bukti lain. Dalam pasal 185 ayat (2) KUHAP berbunyi "keterangan saksi saja tidak cukup untuk membuktikan bahwa terdakwa bersalah terhadap perbuatan yang didakwakan kepadanya".Maka dipertegas didalam pasal 185 ayat (3) KUHAP berbunyi "ketentuan sebagaimana dimaksudkan dalam ayat (2) tidak berlaku apabila disertai suatu alat bukti sah lainnya". Alat bukti lain yang sah diantaranya keterangan ahli, petunjuk, surat, dan keterangan terdakwa.

Berkaitan dengan kesaksian para terdakwa sebagai saksi mahkota harus mempunyai kesesuaian dengan alat bukti lain yaitu memberikan keterangan terkait yaitu adanya shabu yang diakui saksi Albert dari hasil penjualan dengan saudara Jefri. Keterangan Albert mempunyai kesesuaian dengan keterangan terdakwa Jefri.Dengan adanya kesesuaian keterangan Albert dengan keterangan terdakwa, maka keterangan Albert sebagai saksi mahkota bernilai sebagai alat bukti keterangan saksi karena adanya kesesuai antara Albert dan Terdakwa sesuai pasal 185 ayat 3 KUHAP.Dan keterangan Albert sebagai saksi mahkota memiliki fungsi dan tujuan yaitu melengkapi salah satu alat bukti dengan menjadi saksi dimana yang bertujuan untuk mengungkap suatu perkara tindak pidana Narkotika.

Peranan Albert memberikan keterangan sebagai saksi mahkota atas terdakwa Jefri mempunyai nilai pembuktian sebagai alat bukti saksi. Keterangan Albert 
menyatakan bahwa 1 (satu) paket shabu dengan berat 30,14 gram yang dibungkus dengan plastik klip putih bening selanjutnya dibungkus lagi dengan kertas alumunium foil yang ditemukan pada saat terdakwa ditangkap oleh Ditresnarkoba merupakan suruhan dari albert.

Pengunaan saksi mahkota menimbulkan dua konsekwensi dalam prakteknya. Penolakan terhadap keberadaan saksi mahkota dikarenakan dikhawatirkan akan memberikan keterangan yang tidak sesuai kerena adanya permufakatan jahat. Sedangkan konsekuensi selanjutnya adalah keterangan saksi mahkota merupakan keterangan atau alat bukti terkuat dalam terjadainya suatu tindak pidana.Hal ini disebabkan saksi mahkota adalah orang yang terlibat langsung dalam tindak pidana yang terjadi.

\section{B. Penerapan Pidana Pada Putusan Nomor 400/Pid Sus/2019/PN.Pdg Dengan 401/Pid Sus/2019/PN.Pdg Dan Putusan Nomor 09 /Pid Sus/2019/Pn.Pdg Dengan 10/Pid Sus/2019/PN.Pdg}

Dikaji dari optik hukum pidana materil maka Undang-Undang Nomor 35 Tahun 2009 Tentang Narkotika mempunyai beberapa sistem jenis perumusan sanksi pidana Dalam penerapan sanksi Pidana terhadap pelaku narkotika diawali dengan surat dakwaan Penuntut Umum (biasanya pasal-pasal yang didakwakan berbentuk alternatif yaitu Pertama Pasal 114 ayat (1) atau kedua Pasal 112 ayat (1) atau ketiga Pasal 127 ayat (1),(2), dan (3) Undang-Undang Nomor 35 Tahun 2009 kemudian fakta hukum yang ditemukan akan menentukan posisi terdakwa apakah masuk dalam salah satu pasal yang sesuai.

Hakim akan menjatuhkan hukuman bagi terdakwa yang terbukti berdasarkan fakta hukum dan pasal-pasal yang didakwakan oleh penuntut hukum. Sistem perumusan kumulatif-alternatif secara substansial juga meliputi sistem perumusan tunggal, kumulatif dan alternatif, sehingga secara eksplisit dan implisit telah menutupi kelemahan masing-masing sistem perumusan tersebut.Sistem perumusan kumulatif-alternatif merupakan pola sistem perumusan yang secara langsung adalah gabungan bercirikan nuansa kepastian hukum (rechts-zekerheids) dan nuansa keadilan.Dengan titik tolak adanya gabungan antara nuansa keadilan dan kepastian hukum (rechts-zekerheids) maka ciri utama sistem perumusan ini didalam kebijakan aplikatifnya bersifat fleksibel dan akomodatif.Pada kebijakan formulatif/legislatif masa mendatang atau sebagai ius constituendum dikemudian hari hendaknya pembentuk Undang-Undang lebih baik membuat sistem perumusan yang bersifat kumulatif-alternatif atau campuran.

Pada putusan Putusan Nomor 400/Pid Sus/2019/PN.Pdg dengan Terdakwa JEFRI MARISON BIN MUSBAR PGL Majelis Hakim pada putusannya menyatakan Terdakwa telah terbukti secara sah dan meyakinkan bersalah melakukan tindak pidana tanpa hak atau melawan hukum menawarkan untuk dijual, menjadi perantara dalam jual beli Narkotika Golongan I jenis shabu yang beratnya melebihi 5 (Lima) gram. Hal ini berdasarkan alat bukti utama yaitu keterangan Saksi mahkota yang juga menjadi terdakwa pada perkara yang sama dengan pemeriksaan yang berbeda. Hakim Menjatuhkan pidana terhadap terdakwa berupa pidana penjara selama 12 (dua belas) tahun dan membayar denda sebesar Rp 1.000.000.000,- (satu Milyar Rupiah) subsidair 3 (Tiga) bulan penjara. 
Pada perkara dengan Putusan Nomor 401/Pid Sus/2019/PN Pdg dengan Terdakwa ALBERT JACUB BIN MARZUKI JACUB dimana pada pemeriksaan perkara ini Jefri Marison sabagai saksi mahkota, karena tindak pidana dilakukan secara bersama sama. Hakim Menyatakan terdakwa terbukti bersalah melakukan tindak pidana secara tanpa hak atau melawan hukum dalam hal menawarkan untuk dijual atau menyerahkan Narkotika Golongan I jenis shabu yang beratnya melebihi 5 (Lima) gram dan Menjatuhkan pidana terhadap terdakwa ALBERT JACUB BIN MARZUKI JACUB dengan pidana penjara selama 10 (Sepuluh) tahun dan membayar denda sebesar Rp 1.000.000.000,- (Satu Milyar Rupiah) subsidair 2 (Dua) bulan penjara.

Kedua terdakwa dinyatakan bersalah telah melakukan perbuatan yang melanggar Pasal 114 ayat (2) Undang undang nomor 35 tahun 2009 tentang Narkotika, dimana hal ini terbukti dari keterangan masing masing terdakwa yang menjadi saksi mahkota secara terpisah pada perkara mereka masing masing. Kedua terdakwa telah melakukan jual beli narkotika jenis shabu.

Pada Putusan Nomor 9/Pid Sus /2019/Pn.Padang dengan Putusan Nomor 10/Pid Sus/2019/PN.Pdg terdakwa HENDRI RAMADANI PGL.RAMA bersama-sama dengan ROBY BAYU SAPUTRA Als.TOBING (dalam perkara terpisah) melakukan permufakatan jahat untuk tindak pidana yang tanpa hak atau melawan hukum menawarkan untuk dijual, menjual, membeli, menerima, menjadi perantara dalam jual beli, menukar, atau menyerahkan narkotika golongan I jenis Shabu (Metamfetamina) seberat 0.09 gram (Nol Koma Nol Sembilan) gram. Perbuatan terdakwa sebagaimana diatur dan diancam pidana dalam Pasal 114 ayat (1) UU No. 35 Tahun 2009 Jo pasal 132 ayat (1) UU No. 35 Tahun 2009 tentang Narkotika.

Pada pemeriksaan perkara ini masing masing terdakwa menjadi saksi mahkota pada perkara yang sama dengan pemeriksaan secara terpisah. Pada Putusan Nomor 9/Pid Sus /2019/Pn.Padang terdakwa dinyatakan terbukti sah dan meyakinkan bersalah melakukan tindak pidana Pemufakatan jahat untuk melakukan tindak pidana tanpa hal dan melawan hukum menyimpan, menguasai Narkotika Golongan I dalam bentuk bukan tanaman. Terdakwa HENDRI RAMADANI Pgl. RAMA oleh karena itu dengan pidana penjara selama 4 (Empat) tahun, dan denda sejumlah Rp 800.000.000,- (delapan ratus juta) Rupiah, dengan ketentuan bilamana denda tersebut tidak dibayar maka diganti dengan penjara selama 3 (Tiga) bulan.

Sedangkan pada Putusan Nomor 10/Pid Sus/2019/PN.Pdg dengan Terdakwa ROBY BAYU SAPUTRA dimana juga menjadi saksi mahkota pada perkara dengan terdakwa HENDRI RAMADANI terbukti secara sah dan meyakinkan bersalah melakukan tindak pidana "pemufakatan jahat untuk melakukan tindak pidana tanpa hak dan melawan hukum memiliki, menyimpan, menguasai Narkotika Golongan I dalam bentuk bukan tanaman sebagaimana dakwaan subsidair Penuntut Umum. Roby dipidana penjara selama 4 (Empat) Tahun, dan denda sejumlah Rp 800.000.000,- (Delapan Ratus Juta Rupiah), dengan ketentuan bilamana denda tersebut tidak dibayar maka diganti dengan penjara selama 3 (Tiga) bulan.

Tindak pidana Narkotika tidak lagi dilakukan secara perseorangan, melainkan melibatkan banyak orang yang secara bersama-sama, bahkan merupakan satu sindikat yang terorganisasi dengan jaringan yang luas yang bekerja secara rapi dan sangat rahasia 
baik di tingkat nasional maupun internasional. Karena itu untuk menimbulkan efek jera terhadap pelaku penyalahgunaan dan peredaran gelap Narkotika dan Prekursor Narkotika, diatur mengenai pemberatan sanksi pidana, baik dalam bentuk pidana minimum khusus, pidana penjara 20 (dua puluh) tahun, pidana penjara seumur hidup, maupun pidana mati. Undang Undang Nomor 35 Tahun 2009 mengatur mengenai ketentuan pidana minimum khusus karena tindak pidana narkotika merupakan salah satu kejahatan yang berat dan serius. Pemberatan sanksi pidana dalam UU No. 35 Tahun 2009 dapat dilihat dari sifatnya yaitu kumulatif yang berarti bahwa apabila seseorang terbukti melakukan tindak pidana narkotika maka akan dikenakan hukuman pidana penjara dan pidana denda.

\section{PENUTUP}

Pada pertimbangan Hakim dapat diperhatikan keterangan saksi mahkota yang menjelaskan peran dari setiap pelaku tindak pidana. Aparat penegak hukum pidana hendaknya memahami dengan benar dan bertanggung jawab mengenai peran saksi mahkota dalam pembuktian perkara pidana di Indonesia. Agar saksi mahkota memenuhi kewajiban sebagaimana mestinya dan diberikan perlindungan kepadanya, dan jika kemudian ia terbukti bersalah harus dihukum seadil adilnya.

\section{REFERENSI}

Kansil C.S.T , Pengantar Ilmu Hukum Dan Tata Hukum Indonesia, Balai Pustaka, Jakarta, 1989

Muhadar, Edi Abdullah dan Husni Trhamrin, Perlindungan Saksi dan Korban Dalam Sistem Peradilan Pidana, CV. Putra Media Nusantara, Surabaya, 2009

Waluyadi, Kejahatan, Pengadilan dan Hukum Pidana, CV. Mandar Maju, Bandung, 2009

Undang-undang Dasar Negara Republik Indonesia Tahun 1945

Undang Undang Nomor 8 Tahun 1981 tentang Kitab Undang undang Hukum Acara Pidana. 